\title{
Simultaneous detection of pork and wild boar meat in chicken sausages using the combination of a single primer and real-time polymerase chain reaction (qPCR)
}

\author{
Nurull Hikmah ${ }^{1}$, Rumiyati ${ }^{1}$, Sismindari ${ }^{1}$, Abdul Rohman*1,2 \\ ${ }^{1}$ Department of Pharmaceutical Chemistry, Gadjah Mada University, Yogyakarta \\ ${ }^{2}$ Institute of Halal Industry and Systems (IHIS), Gadjah Mada University, Yogyakarta \\ Sekip Utara, Yogyakarta, Indonesia
}

Accepted: 03-03-2020

\begin{abstract}
The identification of meat species in food products and pharmaceuticals is vital to minimize food adulteration practices. Due to its specificity, polymerase chain reaction (PCR)-based methods are the most commonly reported methods for detection of food adulterants. This study was aimed to evaluate the use of real-time PCR with a species-specific primer to identify two non-halal types of meat, namely pork and wild boar meat (WBM), in chicken sausages. The primer was designed using online software PrimerQuest from NCBI (National Center for Biotechnology Information) to target the mitochondrial ND1 gene of Sus scrofa domestica. The annealing temperature (Ta) of the primer used during real-time PCR analysis was optimized to achieve the highest response fluorescence unit at the lowest cycles. Real-time PCR using the primers of NK-ND1-Ssc1 (Forward: 5' AAAGGACCCAACGTTGTAGG 3' and Reverse: 5' TAGTGCTAGGGATAAGGCTAGG 3') was validated with several parameters, namely specificity, the limit of detection for sensitivity, linearity, efficiency, and repeatability. The optimum annealing temperature of NK-ND1-Ssc1 was $58.1^{\circ} \mathrm{C}$. The sensitivity evaluation revealed that the limits of detection (LoD) of pork and WBM in reference sausage samples containing $100 \%$ pork and WBM were $500 \mathrm{pg}$ and $50 \mathrm{pg}$, respectively, which correspond to $0.3 \%$ meat in sausage products. The efficiency values of real-time PCR amplification were $93.1 \%$ and $94.8 \%$ for pork and WBM with coefficient variations of $0.2884 \%$ and $0.4998 \%$, respectively. The validated method was subsequently applied to analyze the commercial samples, and among the twelve (12) samples evaluated, there was one sample positive of containing non-halal meat (pork or WBM). Real-time PCR using species-specific primers, e.g., NK-ND1-Ssc1, is specific and sensitive; therefore, this method can be used as an alternative technique for authentication of halal meat.
\end{abstract}

Keywords: real-time PCR, non-halal meat, halal authentication, species-specific primer

\footnotetext{
*Corresponding author:

Abdul Rohman

Department of Pharmaceutical Chemistry, Institute of Halal Industry and Systems (IHIS)

Gadjah Mada University, Sekip Utara, Yogyakarta, Indonesia

Email: abdulrohmanugm@gmail.com
} 


\section{INTRODUCTION}

Muslims currently constitute a quarter of the world population, and this share is predicted to increase (Hackett, 2015). In response to this, the halal markets in the halal industry are growing exponentially and are estimated to reach more than US\$ 1.6 trillion (Lever and Miele, 2012). The authentication of meat and meat-based food products, especially related to halal and non-halal meats, is an emerging issue in Islamic countries. Halal meat authentication has become a serious matter of grave concern for not only consumers but also food producers and meat stakeholders (Pang et al., 2017; Lubis et al., 2016). The common cases of meat adulteration disclosed in recent years are the substitution of pork and wild boar meat (WBM), which are non-halal, for halal meat such as beef.

The authentication of halal meat-based food requires accurate, reliable, and validated methods to unambiguously confirm the animal species in a variety of degraded and processed food matrices, such as sausages and meatballs. When available, standard methods can protect both producers and consumers from any adulteration practices and prevent illegal trafficking or overexploitation of animal species (Teletchea et al., 2005). There have been numerous publications reporting developed and validated methods for confirmation and identification of meat species in food products. They typically rely upon lipid-based biomarkers, such as in ultraviolet-visible spectroscopy (Alamprese et al., 2013), FTIR or Fourier transform infrared spectroscopy (Rahmania et al., 2015), chromatographic-based techniques (Chou et al., 2007), and protein-based tests like enzyme-linked immunosorbent assay (ELISA) using a specific immunoassay (Asensio et al., 2008; Rao et al., 2016). In certain conditions during food processing, these biomarkers are subject to extensive breakdown or degradation (Ali et al., 2018; Karabasanavar et al., 2014).

DNA-based identification of meat species has evolved as the most commonly used method because it offers several major advantages, including fast and reliable detection, cost efficiency, and suitability for in situ detection systems, especially after the 2013 "Horse Meat Scandal" in parts of Europe. Undeclared or improperly declared horse meat was found in foods advertised as containing beef (O'Mahony, 2013). In the context of meat species detection, the application of DNA has resulted in accurate confirmation and identification of meat present in numerous types of foods, regardless of how the meat-based food has been processed because DNA is more resistant and thermostable than protein (Cravero et al., 2019). DNA is a very stable and long-lived biological molecule that can be retrieved from any substrate because it exists in almost all cells of an organism (Mafra et al., 2008).

Polymerase chain reaction (PCR) and its development, such as real-time PCR, multiplex PCR, TaqMan real-time PCR, are among easily performed DNA-based techniques commonly used for halalmeat authentication. Real-time PCR using primers that are specific for certain species has been used to detect non-halal meats, e.g., pork (Orbayinah et al., 2019), wild boar meat (Widyasari et al., 2015), rat meat (Aina et al., 2019), dog meat in meatball products (Aina et al., 2019), and cat meat in burgers (Ali et al., 2015). In this study, pork and wild boar meat are identified using a newly designed primer targeting mitochondrial DNA.

\section{MATERIALS AND METHODS \\ Materials \\ Experimental materials}

Wild boar meat (WBM) was obtained from several hunters in Baamang District, Kotawaringin Timur Regency, the Province of Kalimantan Tengah, Indonesia. Meanwhile, pork was obtained from Godean District, Sleman Regency, D.I. Yogyakarta Province, Indonesia. As for other meats, they were collected from several regions in Yogyakarta, Indonesia: beef, goat meat, and chicken were purchased from Mlati District in Sleman, Yogyakarta, rabbit meat was obtained from Kaliurang District in Sleman, Yogyakarta, and dog meat was obtained from Bantul Regency in Yogyakarta, Indonesia.

Pharmaciana Vol. 10, No. 1, March 2020, Page. 11 - 22 


\section{Primer design}

The forward (F) and reverse (R) primers of NK-ND1-Ssc1 were designed in silico using PrimerQuest software from Integrated DNA Technologies. The complete DNA sequence and the ND1 subunit of the mitochondrial genome (AP003428.1) of Sus scrofa domestica used for primer design were retrieved from NCBI GenBank. The primer specificity was checked in silico using NCBI PrimerBLAST and compared with beef, goat meat, chicken, rabbit meat, and dog meat. The designed primers (NK-ND1-Ssc1) were:

Forward: AAA GGA CCC AAC GTT GTA GG

Reverse: TAG TGC TAG GGA TAA GGC TA GG

These primers have a melting temperature of $57.84^{\circ} \mathrm{C}(\mathrm{F}$ and $\mathrm{R})$ and $\mathrm{GC}$ contents of $50 \%(\mathrm{~F})$ and $50 \%$ (R) with an amplicon size of 147 base pairs (bp) in length.

\section{Methods}

\section{The extraction and evaluation of DNA}

The DNAs used for PCR assay were extracted manually using a mixture of phenol:chloroform:isoamyl alcohol (PCIA) according to Sambrook et al. (1989). Approximately 200 $\mathrm{mg}$ of the evaluated sample was placed in sterile $2 \mathrm{~mL}$ reaction tubes and added with $800 \mu \mathrm{L}$ of buffer lysis (consisting of EDTA pH 8, Na-acetate $\mathrm{pH} 5.2$, Tris $\mathrm{HCl} \mathrm{pH} \mathrm{8,} \mathrm{NaCl,} \mathrm{and} \mathrm{1 \%} \mathrm{SDS),} 30 \mu \mathrm{L}$ of 20 $\mathrm{mg} / \mathrm{mL}$ proteinase $\mathrm{K}$, and $0.2 \mathrm{~mL}$ of buffer lysis. Then, this mixture was vortexed (Barnstead, USA) for $5 \mathrm{~min}$, incubated in a water bath (IK HB 10, Medford, USA) at a temperature of $55^{\circ} \mathrm{C}$ for $60 \mathrm{~min}$ with occasional shaking (15 min each). The suspension was centrifuged (5 min, 13,000 gm) in a microcentrifuge (Sartorius 3-30K Sigma, Germany). The supernatant $(400 \mu \mathrm{l})$ was pipetted off to a new tube and added with $200 \mu \mathrm{L}$ of cold phenol (Merck, Darmstadt, Germany), creating a homogenous mixture. This solution was then shaken with a shaker in an incubator (Biobase, China) for $30 \mathrm{~min}$, and the suspension was centrifuged at 13,000 $\mathrm{xg}$ for $10 \mathrm{~min}$. The resultant supernatant was removed and subsequently added with chloroform $(1: 1 \mathrm{v} / \mathrm{v})$ and subjected to centrifugation at 13,000 $\mathrm{xg}$ for $10 \mathrm{~min}$. DNA was sedimented with $2.5 \mathrm{M}$ Na-acetate $\mathrm{pH} 5.2(1: 0.1 \mathrm{v} / \mathrm{v})$ and cold absolute ethanol $(1: 2 \mathrm{v} / \mathrm{v})$. The DNA obtained was then washed with $0.25 \mathrm{~mL}$ of $70 \%$ ethanol, dried, and added with $50 \mu \mathrm{L}$ of Tris-EDTA buffer (consisting of $10 \mathrm{mM}$ Tris $\mathrm{HCl} \mathrm{pH} 8$ and $1 \mathrm{mM}$ EDTA). The extraction was performed two times.

\section{Amplification analysis of DNA using PCR}

The extracted DNA was analyzed using qPCR. The reagent $(20 \mu \mathrm{L})$ was composed of $10 \mu \mathrm{L}$ of EvaGreen qPCR master mix, $1 \mu \mathrm{L}$ of the forward primer and reverse primer, $1 \mu \mathrm{L}$ of DNA template $(50 \mathrm{ng} / \mu \mathrm{L})$, and $7 \mu \mathrm{L}$ of nuclease-free water. The conditions used were: pre-denaturation at $95^{\circ} \mathrm{C}$ for $30 \mathrm{sec}(1 \mathrm{cycle})$, denaturation at $95^{\circ} \mathrm{C}$ for $5 \mathrm{sec}$, annealing at an optimized temperature of $58.1^{\circ} \mathrm{C}$ for $30 \mathrm{sec}$, extension or amplification at $72^{\circ} \mathrm{C}$ for $10 \mathrm{sec}$ (cycled for 25 times), and elongation at $72^{\circ} \mathrm{C}$ for 5 min to stabilize the amplification product.

\section{Evaluation of PCR products}

The PCR products were visualized through electrophoresis (i-Mupid J Cosmo Bio Co., Tokyo, Japan) using $2 \%$ agarose in TBE $1 \mathrm{x}$ for $30 \mathrm{~min}$ at $100 \mathrm{~V}$ to examine whether the designed SSP had successfully amplified the DNA. In this test, $4 \mu \mathrm{L}$ of each type of DNA with a concentration of 50 $\mathrm{ng} / \mu \mathrm{L}$ was used. The result was recorded using a transilluminator (Bio-Rad, USA). The resultant band was compared with the DNA marker to determine the size of the amplicon. The DNA marker used was 100 bp DNA ladder (GeneAid, Taiwan) (Orbaniyah et al., 2019). 


\section{Evaluation of reference samples of sausages}

The reference samples used in this study were sausages made from chicken, pork, and wild boar meat (WBM). First, fresh chicken meat (CM), pork (PM) and WBM were washed and drained. Second, the meats (CM, CM-PM-WBM, PM-WBM) were prepared to comprise as much as $90 \%$ of the sausages and, then, mashed and mixed with wheat $(10 \%)$, salt $(0.01 \% \mathrm{wt} / \mathrm{wt})$, and other herbs commonly used in making sausages. This mixture was then wrapped with sausage casing and then cooked in boiling water. The DNA of the reference sausage was extracted and then tested using qPCR. The qPCR methods used were conditioned according to the manufacturer's procedure given (Biotium Inc., Bio-Rad Laboratories, CA, USA). In a reaction tube, $10 \mu \mathrm{L}$ of EvaGreen, $7 \mu \mathrm{L}$ of nuclease-free water, $1 \mu \mathrm{L}$ of $10.0 \mu \mathrm{M}$ forward primer, $1 \mu \mathrm{L}$ of $10.0 \mu \mathrm{M}$ reverse primer, and $1 \mu \mathrm{L}$ of extracted DNA $(50 \mathrm{ng} / \mu \mathrm{L})$ were mixed and analyzed using an instrument (real time-PCR, CFX96 Touch Real-Time PCR Detection System from Bio-Rad, the United States). The qPCR procedure was as follows: predenaturation at $95^{\circ} \mathrm{C}$ for $30 \mathrm{sec}(1 \mathrm{cycle})$, denaturation at $95^{\circ} \mathrm{C}$ for $5 \mathrm{sec}(25 \mathrm{cycles})$, annealing temperature at $58.1^{\circ} \mathrm{C}$ for $30 \mathrm{sec}$, and extension or amplification temperature at $72^{\circ} \mathrm{C}$ for $10 \mathrm{sec}$. The relative fluorescence signals were read at the end of each cycle. In the melting curve analysis, the temperature was set at $65^{\circ} \mathrm{C}-95^{\circ} \mathrm{C}$ with an increment of $0.5^{\circ} \mathrm{C} / 5 \mathrm{sec}$. The evaluation included linearity, efficiency, and sensitivity (Bio-Rad, 2006). The data were processed and analyzed in CFX Maestro ${ }^{\mathrm{TM}}$ software, which is included in the qPCR instrument.

\section{Validation of real-time PCR for quantitative analysis}

The real-time PCR using the primers of NkND1-Ssc-1 was validated based on the guidelines introduced by the Codex Alimentarius Commission, that is, by assessing specificity, linearity, sensitivity (represented by limit of detection and limit of quantification), amplification efficiency, and precision (represented by the repeatability of the developed method). The validated method was then applied to the identification of DNA in commercial meatball samples.

\section{Data Analysis}

The real-time PCR results were analyzed using a standard curve created by comparing $\mathrm{Cq}$ values (Quantification circle) with the log-transformed concentration of DNA. Meanwhile, the realtime PCR efficiency (E) was calculated using the formula: $\mathrm{E}=(10$ (-1/ slope $)-1)$ x 100 (Bio-Rad, 2006).

\section{RESULTS AND DISCUSSION}

\section{Purity and concentration of extracted DNAs}

Extraction of DNA from raw meats or sausage samples is the first step for the successful identification of meat species intended for halal authentication. It can be carried out using the manual procedures of some DNA extraction methods or DNA extraction kits supplied by several manufacturers. 


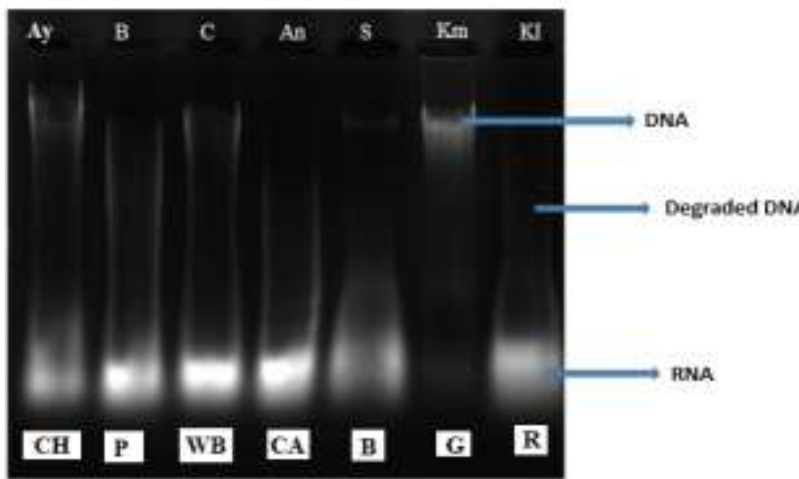

(A)

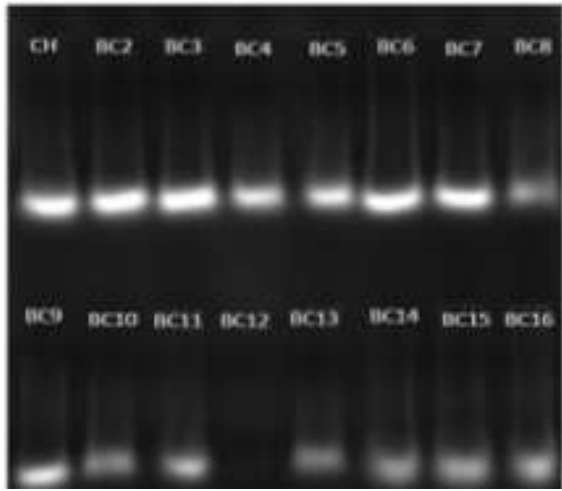

(B)

Figure 1. The agarose-gel electropherograms of DNAs isolated from raw meats. (A) shows DNAs of chicken $(\mathrm{CH})$, pork $(\mathrm{P})$, wild boar (WB) meat, dog meat (CA), beef (B), goat meat (G) and rabbit meat $(R)$, while $(B)$ shows DNAs isolated from the reference samples of sausages made from chicken $(\mathrm{CH})$ and the combination of chicken, pork, and wild boar meat with varying compositions (BC 2-16)

Figure 1 shows the agarose-gel electropherogram of DNAs isolated from raw chicken, pork, wild boar meat, dog meat, beef, goat meat, and rabbit meat (A) and DNAs isolated from the reference samples of sausages made from chicken and the combination of chicken, pork, and wild boar meat with varying compositions. Table I compiles the purity levels and concentrations (yields) of DNAs extracted from several matrices. The extracted DNAs had ratios approaching 1.7-2.0.

Table I. The purity levels and concentrations of DNAs extracted from raw meats and reference samples of sausages containing chicken, pork, and wild boar meat

\begin{tabular}{ccc}
\hline Samples & Ratio $(\mathbf{2 6 0 /} \mathbf{2 8 0} \mathbf{~ n m})$ & Concentration $(\mathbf{n g} / \mathbf{\mu L})$ \\
\hline Chicken & Raw meats & \\
Pork & 1.80 & 3598.89 \\
Wild boar meat & 2.02 & 2350.00 \\
Dog meat & 1.97 & 2840.62 \\
Beef & 1.97 & 2566.28 \\
Goat meat & 1.45 & 2187.76 \\
Rabbit meat & 1.79 & 333.56 \\
& 1.72 & 2537.02 \\
CM without PM-WBM (0\%) & 1.95 & \\
CM-PM-WBM (0.1\%) & 1.79 & 1391.19 \\
CM-PM-WBM (0.3\%) & 1.30 & 1580.29 \\
CM-PM-WBM (0.5\%) & 1.13 & 3180.84 \\
CM-PM-WBM (0.7\%) & 1.15 & 3437.21 \\
CM-PM-WBM (0.9\%) & 1.26 & 3189.88 \\
CM-PM-WBM (1\%) & 1.76 & 3131.77 \\
CM-PM-WBM (2\%) & 1.18 & 234.84 \\
CM-PM-WBM (3\%) & 1.13 & 3364.38 \\
CM-PM-WBM (5\%) & 1.31 & 3333.17 \\
CM-PM-WBM (10\%) & 1.65 & 3185.64 \\
CM-PM-WBM (25\%) & 1.10 & 149.78 \\
CM-PM-WBM (50\%) & 1.11 & 3106.08 \\
CM-PM-WBM (75\%) & 1.64 & 3061.35 \\
PM (100\%) & 1.62 & 1569.25 \\
WBM (100\%) & 1.64 & 2259.71 \\
& & 3155.80 \\
\hline
\end{tabular}




\section{Validation results of real-time $\mathrm{PCR}$}

Figure 2 depicts the amplification curves and denaturation peaks of pork and wild boar meat using primer at various annealing temperatures $(\mathrm{Ta})$. The highest relative fluorescence unit (RFU) during the amplification of DNAs of pork and wild boar meat was obtained at Ta of $58.1^{\circ} \mathrm{C}$

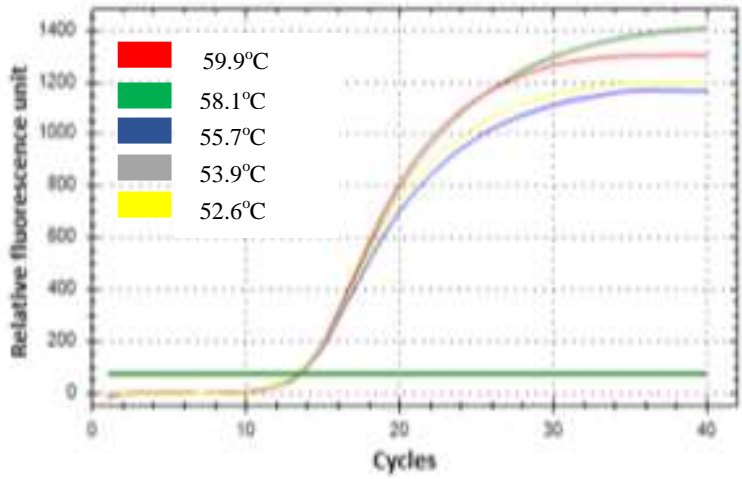

(A)

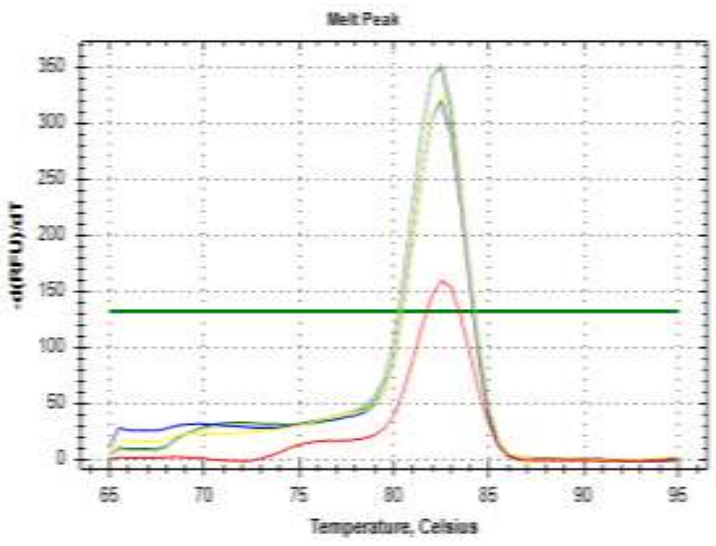

(B)

Figure 2. The amplification curves and denaturation peaks of DNA extracted from pork using the primers of NK-ND1-Ssc1 at various annealing temperatures: $59.9,58.1,55.7,53,9$ and $52.6^{\circ} \mathrm{C}$

Figure 3 shows that the designed primer could amplify DNAs isolated from pork specifically at a melting temperature $(\mathrm{Tm})$ of 82.50 and $\mathrm{WBM}$ at Tm of 83.00 but not DNAs of nontarget species. According to this graph, the annealing temperature of $58.1^{\circ} \mathrm{C}$ can be used in the validation test.

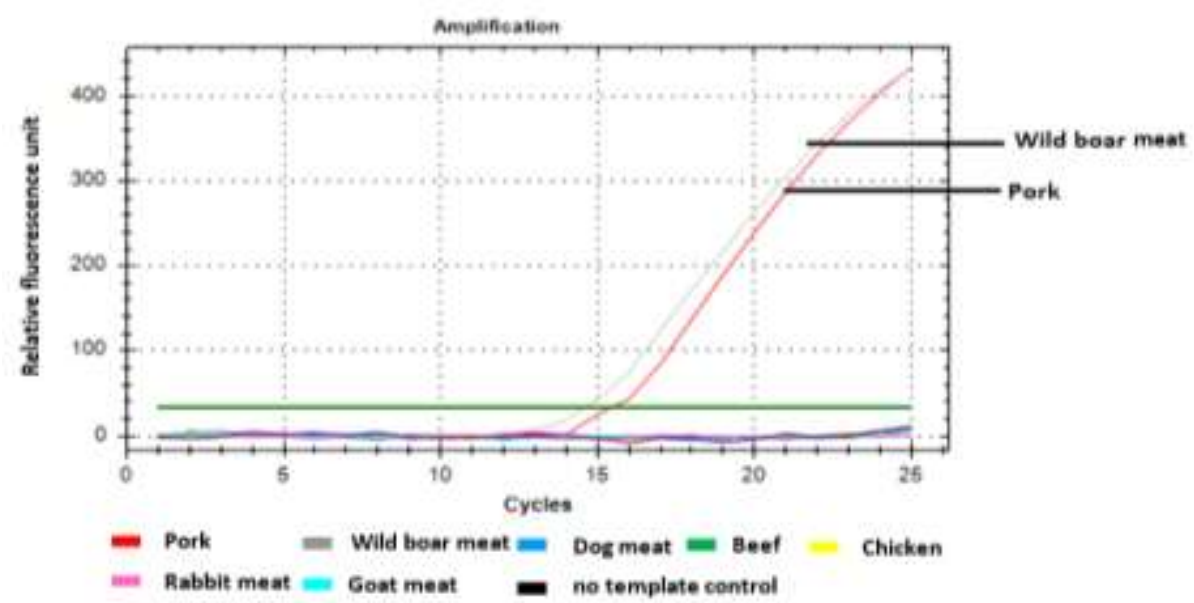

Figure 3. The amplification curves of DNAs isolated from pork, wild boar meat, dog meat, beef, chicken, goat meat, rabbit meat, and no template control (negative control) using the primers of NKND1-Ssc1 at an annealing temperature of $58.1^{\circ} \mathrm{C}$

The results of the sensitivity and efficiency tests are shown in Figures 4 and 5. The DNAs extracted from pork and WBM could be distinguished and amplified when present at the lowest concentration of $50 \mathrm{ng}$; therefore, the limit of detection was $50 \mathrm{ng}$. The linear regression analysis between the log values of porcine DNA concentrations resulted in a coefficient of determination $\left(\mathrm{R}^{2}\right)$ of 0.992 with an efficiency value (E) of $93.1 \%$. As for the analysis of DNA extracted from wild boar meat, the $\mathrm{R}^{2}$ and $\mathrm{E}$ values were $94.8 \%$ and 0.995 , respectively. 


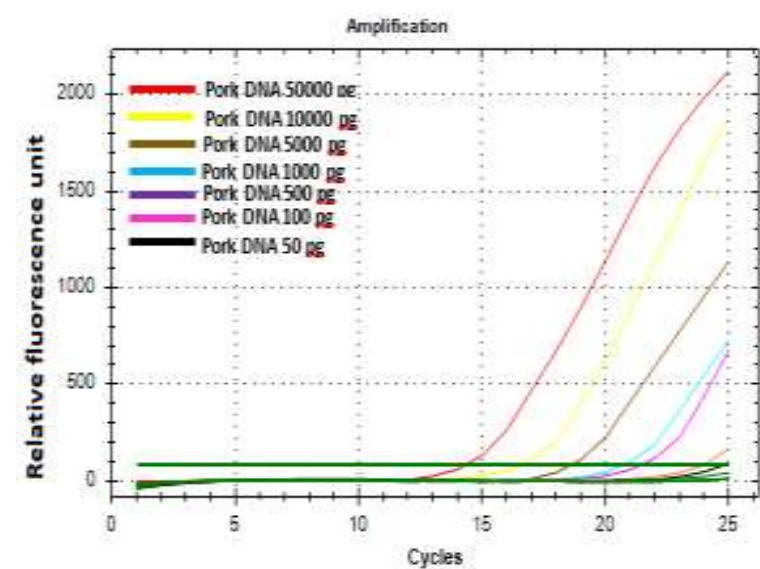

(A)

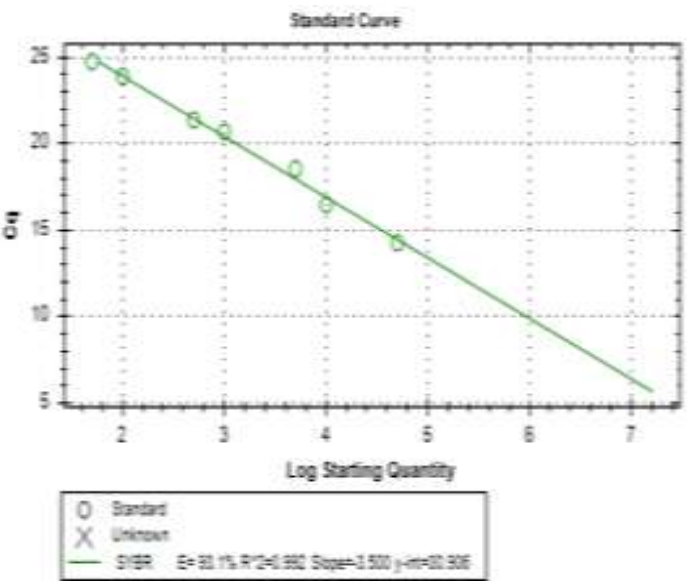

(B)

Figure 4. The amplification curves (A) and the corresponding linear regression (B) between porcine DNA concentration and cycle threshold $(\mathrm{Cq})$ using the primers of NK-ND1-Ssc1 at an annealing temperature of $58.1^{\circ} \mathrm{C}$
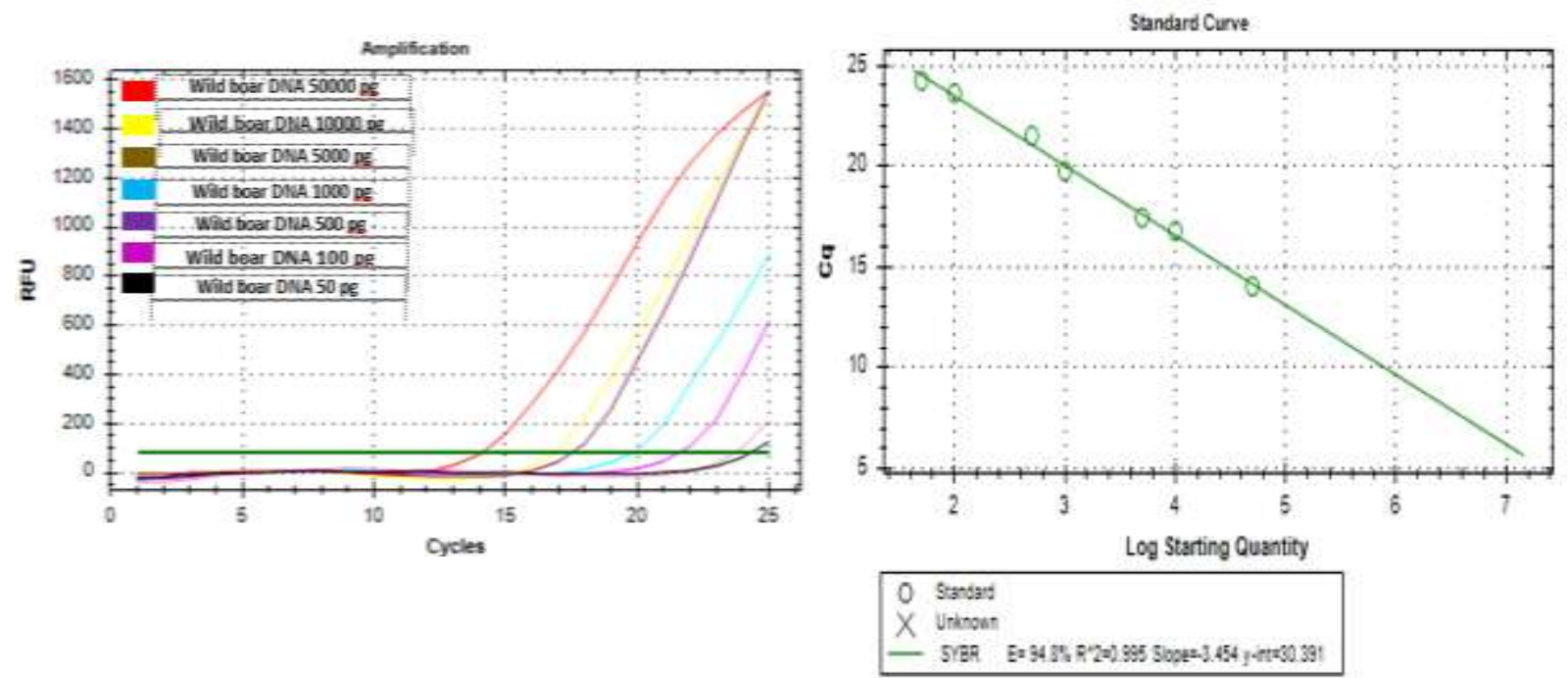

(A)

(B)

Figure 5. The amplification curves (A) and the corresponding linear regression $(B)$ between the concentrations of wild boar meat DNA and cycle threshold (Cq) using the primers of NK-ND1-Ssc1 at an annealing temperature of $58.1^{\circ} \mathrm{C}$

\section{Application of validated methods to real sample analysis}

Figure 6 presents the amplification profiles of DNAs extracted from commercially available sausages. All the evaluated samples did not contain pork and WBM in their formulation. 


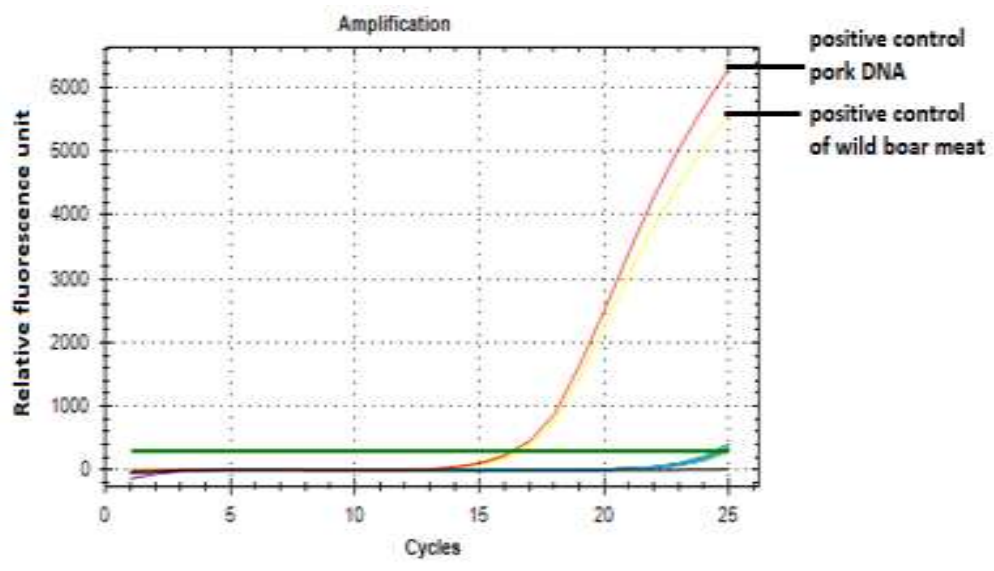

Figure 6. The amplification curves of DNAs extracted from samples of commercial sausages along with positive controls of DNAs extracted from chicken sausages containing pork and wild boar meat

In this study, the manual extraction system of phenol-chloroform-isoamyl alcohol (PCIA) is used for DNAs extraction. However, prior to use, it must be buffered to achieve $\mathrm{pH} 8.0$ or above because DNA can be lost in an acidic condition. The use of SDS and proteinase $\mathrm{K}$ in this extraction system is intended to digest non-nucleic acid components and proteins enzymatically, while the mixture of PCIA is to partition cellular debris and lipid components into the organic phase (the isolated DNA remains in the aqueous phase). Isoamyl alcohol reduces foaming during the extraction process.

Electrophoresis using agarose gel is used to visualize or check the isolated DNAs. Fig. 1(A) shows that all DNAs can be isolated, as indicated by the appearance of DNA bands in agarose gel. However, not every fluorescence band is DNA; it may be RNA, protein, or degraded DNA. In Fig. 1(B), there are smears of DNAs isolated from sausages as a result of heat treatment during cooking, which degrades DNA. Therefore, the yield and purity of the isolated DNAs are necessary to identify. As seen in Table I, the extracted DNAs have high yields (ratios approaching 1.7-2.0), indicating that DNAs are enough to be used in real-time PCR analysis. Furthermore, DNAs with purity levels of far from 1.8-2.0 are not problematic because real-time PCR can amplify them, provided that the mixture of PCR reaction contains a DNA template even in a small quantity.

Before validating the real-time PCR, the conditions used to run it need to be optimized, preferably using annealing temperature. NK-ND1-Ssc1 is a specific primer designed in silico using NCBI Primer-BLAST (Basic Local Alignment Search Tool) targeting the chromosomal DNA of pork (Sus scrofa domesticus), wild boar meat (Sus scrofa), beef (Bos indicus), chicken (Gallus gallus), dog meat (Canis lupus familiaris), goat meat (Capra hircus), and rabbit meat (Leporidae). The optimization of annealing temperature is essential in optimizing the attachment of the designed primer to the DNA template. The annealing temperature $(\mathrm{Ta})$ is selected based on its capability to produce the highest signal (relative fluorescence unit, RFU) with the lowest cycles. The average annealing temperatures of the forward primer and reverse primer are estimated to be $57.73^{\circ} \mathrm{C}$ and $57.93^{\circ} \mathrm{C}$, respectively. Therefore, some temperatures in the range of $53.9^{\circ} \mathrm{C}-59.9^{\circ} \mathrm{C}$ are preferable, namely 59.9 , $58.1,55.7,53.9$, and $52.6^{\circ} \mathrm{C}$. Figure $2(\mathrm{~A})$ displays the amplification curves and denaturation peaks of pork using primer at various annealing temperatures. Based on the highest RFU values (1200) and lowest cycles (14.92), the annealing temperature of real-time PCR for pork identification is $58.1^{\circ} \mathrm{C}$, with the melting temperature (Tm) of 82.50 .

Pharmaciana Vol. 10, No. 1, March 2020, Page. 11 - 22 
The amplification of NK-ND1-Ssc1 primer for the detection of DNA of wild boar meat also uses the same annealing temperature as that of pork DNA. At Ta of $58.1^{\circ} \mathrm{C}$, the highest RFU is 1400 , with a quantification cycle $(\mathrm{Cq})$ of 13.30 and Tm of 83.00, as shown in Figure 2(B). Furthermore, this Ta has been used in the specificity tests of DNAs extracted from wild boar meat (Sus scrofa), beef (Bos indicus), chicken (Gallus gallus), dog meat (Canis lupus familiaris), goat meat (Capra hircus), and rabbit meat (Leporidae).

NK-ND1-Ssc1 can be used to amplify DNAs isolated from pork, wild boar meat, dog meat, beef, chicken, goat meat, rabbit meat, and no template control (negative control) at an annealing temperature of $58.1^{\circ} \mathrm{C}$, and the amplification curve produced is shown in Figure 3. The forward and reverse primers can amplify DNAs isolated from pork and wild boar meat at Tm of 82.50 and 83.00 , respectively, but cannot amplify DNAs from other meats. This means that the designed primers can specifically amplify the DNAs of pork and WBM simultaneously, which, in the case of halal authentication, provides an advantage because both types of meat are non-halal. As a consequence, using one single primer, both non-halal types of meat can be amplified, while DNAs from halal meats are not amplified.

The sensitivity of real-time PCR using the primers of NK-ND1-Ssc1 for detection of pork and WBM can be evaluated by determining the lowest concentrations of DNAs that can amplify the DNA templates, or termed limit of detection (LoD). The sensitivity is measured from the intercept of the linear regression between $\mathrm{Ct}$ or Cycle threshold (y-axis) and the log values of DNA concentrations ( $\mathrm{x}$ axis) from the serial dilutions of DNAs of raw pork and WBM at $50000 \mathrm{pg}, 10000 \mathrm{pg}, 5000 \mathrm{pg}, 1000$ $\mathrm{pg}, 500 \mathrm{pg}, 100 \mathrm{pg}$, and $50 \mathrm{pg}$, as well as the serial dilutions of DNAs extracted from sausages containing $100 \%$ pork and $100 \%$ WBM. The amplification curves are shown in Figures 5 and 6. DNAs of pork and WBM can be amplified at the lowest concentration of $50 \mathrm{ng}$, while, at a lower concentration $(<50 \mathrm{pg})$, no amplified DNA is observable until the $30^{\text {th }}$ cycles. Therefore, the LoD of DNAs of pork and wild boar meat using NK-ND1-Ssc1 is $50 \mathrm{pg}$ (Ali et al., 2013).

The amplification efficiency of NK-ND1-Ssc1 can be assessed using the linear regressions presented in Figures 4 and 5. The linear regression between $\mathrm{Cq}$ and the $\log$ values of porcine DNA concentrations shows a coefficient of determination $\left(\mathrm{R}^{2}\right)$ of 0.992 with an efficiency value (E) of 93.1\%. Meanwhile, the $\mathrm{R}^{2}$ and $\mathrm{E}$ values of the DNA of WBM are $94.8 \%$ and 0.995 , respectively. All of which have met the qualitative and quantitative test criteria set by the Codex Alimentarius Commission (2010), i.e., $\mathrm{R}^{2} \geq 0.98$ and $\mathrm{E}$ of $90-110 \%$. Based on the repeatability test results, the coefficient values $(\mathrm{CV})$ of $\mathrm{Cq}$ are $0.22 \%$ and $0.50 \%$ for DNAs extracted from pork and WBM, respectively. The $\mathrm{CV}$ values fall within the acceptance criteria according to $\mathrm{CAC}$ (Codex Alimentarius Commission/GL 74, 2010). i.e., CV for real-time PCR $\leq 25 \%$ (Sow et al., 2017). The real-time PCR method developed in this study has also been applied to the detection of pork and WBM in commercial chicken sausages. Twelve commercial samples collected from several areas in Yogyakarta, Indonesia, show no amplification. Also, Figure 6 presents that only positive controls (DNAs extracted from chicken sausages containing pork and WBM) are amplified, meaning indicated that the evaluated samples of chicken sausages do not contain pork and WBM in their formulations.

\section{CONCLUSION}

Real-time PCR using NK-ND1-Ssc1, a designed primer, at an annealing temperature of $58.1{ }^{\circ} \mathrm{C}$ has been successfully validated and used for identification of pork and wild boar meat in chicken sausages. The combination of real-time PCR and NK-ND1-Ssc1 can be used for the analysis of pork and WBM (non-halal meats), although it cannot differentiate pork from WBM. The developed method can be used as an alternative for halal authentication analysis. 


\section{ACKNOWLEDGMENT}

The authors would like to acknowledge the Ministry of Research and Higher Education of the Republic of Indonesia for granting financial assistance under the scheme of Penelitian Terapan Unggulan Perguruan Tinggi (PTUPT) in 2019, with a contract number of 2717/UN1.DITLIT/DITLIT/LT/2019.

\section{REFERENCES}

Aina, G. Q., Erwanto E., Hossain, M., Johan, M. R., Ali, M. E. and Rohman, A., 2019, The employment of qPCR using specific primer targeting on mitochondrial cytochrome-b gene for identification of wild boar meat in meatball samples, Journal of Advanced Veterinary and Animal Research, 6(3): 300-307.

Alamprese, C., Casale, M., Sinelli, N., Lanteri, S. and Casiraghi, E., 2013, Detection of minced beef adulteration with turkey meat by UV-vis, NIR and MIR spectroscopy, LWT-Food Science and Technology, 53: 225-232.

Ali, M. E., Rahman, M. M., Hamid, S. B. A., Mustafa, S., Bhassu, S., Hashim, U., 2013, Caninespecific PCR assay targeting cytochrome $b$ gene for the detection of dog meat adulteration in commercial Frankfurters, Food Analytical Methods, 7: 234-241.

Ali, M. E., Amin, M., Razzak, M. A., Hamid, S. B. A., Rahman, M. M. and Rashid, N. R. A., Asing, A., 2015, Short amplicon-length PCR assay targeting mitochondrial cytochrome $b$ gene for the detection of feline meats in burger formulation, Food Analytical Methods, 9(3): 571-581.

Ali, M. E., Ahamad, M. N. U., Asing, A., Hossain, M. A. M. and Sharmin, S., 2018, Multiplex polymerase chain reaction-restriction fragment length polymorphism assay discriminates of rabbit, rat and squirrel meat in frankfurter products, Food Control, 84: 148-158.

Asensio, L., González, I., García, T. and Martín, R., 2008, Determination of Food Authenticity by Enzyme-Linked Immunosorbent Assay (ELISA), Food Control, 19: 1-8.

Bio-Rad, 2006, Real-Time PCR Application Guide, USA: Bio-Rad Laboratories, Inc.

Chou, C. C., Li, S. P., Lee, K. M., Hsu, C. T., Vickroy, T. W. and Zen, J. M., 2007, Fast Differentiation of Meats from Fifteen Animal Species by Liquid Chromatography with Electrochemical Detection using Copper Nanoparticle Plated Electrodes, Journal of Chromatography B, 846: 230-239.

Codex Alimentarius Commission/GL 74, 2010, Codex Guidelines on Performance Criteria and Validation of Methods for Detection, Identification, and Quantification of Specific DNA Sequences and Specific Proteins In Foods.

Cravero, D., Cerutti, F., Maniaci, M. G., Barzanti, P., Scaramagli, S. M. V. and Riina, A., 2019, Evaluation of DNA Isolation Procedures from Meat-based Foods and Development of a DNA Quality Score, LWT - Food Science and Technology, 106: 64-71.

Hackett, C., Connor, P., Stonawski, M., Skirbekk, V., Potancokova, M. and Abel, G., 2015, The Future of World Religions: Population Growth Projections, 2010-2050, In Stencel S, Lipka M, Sandstrom, A. (Eds.), Washington, DC, Pew Research Center. Overview: 5-23.

Karabasanavar, N. S., Singh, S., Kumar, D. and Shebannavar, S. N., 2014, Detection of pork adulteration by highly-specific PCR assay of mitochondrial D-loop, Food Chemistry, 145: 530-534.

Lever, J. and Miele, M., 2012, The growth of halal meat markets in europe: an exploration of the supply-side theory of religion. Journal of Rural Studies, 28: 528-537.

Lubis, H. N., Mohd-Naim, N. F., Alizul, N. N., Ahmed, M. U., 2016, from market to food plate: current trusted technology and innovations in halal food analysis, Trends in Food Science and Technology, 58: 55-68.

Mafra, I., Silva, S. A., Moreira, E. J. M. O., da Silva C. S. F., Beatriz, M, and Oliveira, P. P., 2008, Comparative study of DNA extraction methods for soybean derived food products. Food Control, 19(12):1183-1190. 
Orbayinah S, Rohman A, Widada H, Hermawan A. and Sismindari, 2019, Application of real-time polymerase chain reaction using species-specific primer targeting on mitochondrial cytochrome $\mathrm{b}$ gene for analysis of pork in meatball products. Journal of Advanced Veterinary and Animal Research, 6(2): 260-265.

O'Mahony, P. J., 2013, Finding horse meat in beef products a global problem, QJM: An International Journal of Medicine, 106(6):106: 595-597.

Pang, Z., Deeth, H., Yang, H., Prakash, S. and Bansal, N., 2017, Evaluation of tilapia skin gelatin as a mammalian gelatin replacer in acid milk gels and low-fat stirred yogurt, Journal of Dairy Science, 100: 3436-3447.

Rahmania, H., Sudjadi, and Rohman, A., 2015, The employment of FTIR spectroscopy in combination with chemometrics for analysis of rat meat in meatball formulation, Meat Science, 100:301-305.

Rao, Q., Richt, J. A. and Hsieh, Y. H. P., 2016, Immunoassay for the detection of animal central nervous tissue in processed meat and feed products. Journal of Agricultural and Food Chemistry, 64: 3661-3668.

Sambrook, J., Fritsch, E. F. and Maniatis, T., 1989, Molecular Cloning: A Laboratory Manual. New York, USA: Cold Spring Harbor Laboratory Press.

Sow, L. C., Peh, Y. R., Pekerti, B. N., Fu, C., Bansal, N. H. and Yang, A., 2017, Nanostructural analysis and textural modification of tilapia fish gelatin affected by gellan and calcium chloride addition, LWT-Food Science and Technology, 85: 137-145.

Teletchea, F., Maudet, C. and Ha"nni, C., 2005, Food and forensic molecular identification: update and challenges, Trends in Biotechnology, 23: 359-366.

Widyasari, Y. I., Sudjadi and Rohman, A., 2015, Analysis of rat meat in meatball formulation using real-time polymerase chain reaction, Asian Journal of Animal Science, 9(6): 460-465. 
Pharmaciana Vol. 10, No. 1, March 2020, Page. 11 - 22 